UDC 633.11: 631.526.3

DOI https://doi.org/10.32851/2226-0099.2021.118.3

\title{
RESEARCH ON THE PRODUCTIVITY OF THE VARIETAL COMPOSITION OF WINTER WHEAT UNDER THE CONDITIONS OF THE SOUTHERN STEPPE OF UKRAINE
}

\author{
Berdnikova O.G. - Candidate of Agricultural Sciences, \\ Associate Professor at the Department of Agriculture, \\ Kherson State Agrarian and Economic University \\ orcid.org/0000-0002-7217-1672 \\ Kucherak E.M. - Postgraduate Student at the Department of Agriculture, \\ Kherson State Agrarian and Economic University \\ orcid.org/0000-0002-9853-7724
}

The introduction of new winter wheat varieties into production is a way to increase profitability of cultivation. Winter wheat is the main food crop in our country. The productivity and profitability of winter wheat production mainly determines the level of welfare of agricultural commodity producers. Unfortunately, the average productivity of this crop in Ukraine is two and a half times lower than that of the countries of Western Europe. This situation is caused by many factors, one of which is the use of seeds of low generations for sowing and obsolete varieties that do not meet modern requirements of highly intensive agriculture. Flexibility in the crop varietal structure has positive results. The crop varietal composition is formed for the following year on the basis of registered and promising varieties and hybrids, but only a part of them can be used on each individual farm. One of the main areas of selection of high-yielding varieties of wheat is to reduce the height of the stem. This is due not only to the need to increase the resistance of plants to lodging, but also the tendency to increase grain yields due to straw yields. Quite high yields of new intensive varieties of wheat can be obtained with thickened stems, increasing the number of grains in the ear, as well as increasing the protein content in the grain. The variety of climatic conditions in Ukraine explains the fact that in the western regions with mild winters and more rainfall, high yields are produced by late-ripening varieties of the Western European ecological type.

Goal. The main purpose of the research was to determine the productivity of winter wheat varieties both under irrigation and without irrigation.

Methods. Common methods of field and laboratory research were used, namely:

- visual and measuring-weight - to monitor the phases of development and determine the biometric indicators of plants, their productivity;

- biochemical - to determine quality indicators;

- hypotheses, analysis, synthesis, abstraction - in formulating the purpose and objectives of research, generalization of the results and substantiation of conclusions;

- mathematical and statistical - to assess the reliability of the obtained research results;

Key words: winter wheat, variety, grain quality, disease resistance, plant height, tilling capacity, winter hardiness, interphase period, vegetation, sowing density, plant morphobiotype.

Берднікова О.Г., Кучерак Е.М. Дослідження продуктивності сортового складу пиениці озимої в умовах Південного Степу Украӥни

Впровадження нових сортів озимої пиениці у виробництво - илях до збільшення рентабельності ї̈ вирощування Озима пшеничя - основна продовольча культура в нашій державі. Саме ї̈ врожайність і рентабельність вирощування значною мірою визначають ступінь добробуту сільськогосподарських товаровиробників. На превеликий жаль, середня врожайність иієї культури в Україні в 2,5 раза нижча, ніж у країнах Західної Європи. Такий стан речей зумовлений багатьма чинниками, одним із яких є використання для посівів насіння невисокої репродукиї та застарілих сортів, щуо не відповідають сучасним вимогам високоінтенсивного землеробства. Маневрування у сортовій структурі посівів дає позитивні результати. Сортовий склад посівів на кожний наступний рік формується, виходячи із зареєстрованих та перспективних сортів і гібридів, але в кожному окремому господарстві може використовуватися лише частина з них. Одним з основних напрямів 
селекиї високоврожайних сортів пшенииі є зменшення висоти стебла. Це зумовлено не лише потребою підвищення стійкості рослин проти вилягання, а й тенденцією збільшення врожаїв зерна за рахунок урожаїв соломи. Досить високі врожаї нових інтенсивних сортів пшениці можна мати при загущеному стеблостої, збільшенні кількості зерен у колоску, а також при підвищенні вмісту білка в зерні. Різноманітністю кліматичних умов в Україні пояснюється те, що в західних областях із м'якими зимами і більшою кількістю опадів високі врожаї дають пізньостиглі сорти західноєвропейського екологічного типу.

Мета. Основною метою досліджень було визначення продуктивності сортів пшениці озимої як в умовах зрошення, так $і$ без зрошення.

Методи. Використовувалися загальноприйняті методи досліджень - польовий і лабораторний, а саме:

- візуальний $і$ вимірювально-ваговий - для спостереження за фазами розвитку та визначення біометричних показників рослин, їх продуктивності;

- біохімічний - для визначення якісних показників;

- гіпотез, аналізу, синтезу, абстрагування - під час формулювання мети та завдань досліджень, узагальнення одержаних результатів і обтрунтування висновків;

- математично-статистичний - для оиінки достовірності отриманих результатів досліджень.

Висновки. У статті розкрито теоретичне узагальнення та нове вирішення завдання підвищення продуктивності озимої пшениці на основі добору кращих взаємодоповнюючих сортів в умовах конкретного регіону.

Ключові слова: озима пшениия, сорт, якість зерна, стійкість до хвороб, висота рослин, зимостійкість, урожайність, міжфазний період, вегетачія, густота посіву, морфобіотип рослин.

Problem statement. Wheat takes an important place in terms of food significance and production scale. Introducing new winter wheat varieties into production is the way to increase profitability of wheat cultivation. Winter wheat is a main food crop in our country. Its productivity and production profitability mainly determine the level of agricultural commodity producers' welfare. Unfortunately, the average productivity of this crop in Ukraine 2.5 times lower than its productivity in the countries of Western Europe. Such a situation is explained by many factors, one of them is the use of seeds of early generations and obsolete varieties that do not meet modern requirements of highly intensive agriculture. Under current conditions, when the improvement of crop variety takes 6-8 years, research in plant breeding centers of the world and Ukraine aims at creating new highly productive varieties with high yielding capacity, increased resistance to a complex of diseases, unfavorable weather conditions and high indexes of grain quality. Close collaboration of the professionals of the farm "Sady Ukrainy" with the leading plant breeding centers (the Institute of Breeding and Genetic, the Institute of Plant Physiology and Genetics, Myronivka Institute of Wheat, Krasnodar Breeding Institute) has contributed to obtaining high annual yields.

Analysis of the previous studies. An increase in production of food grain of soft wheat mainly depends on the potential capabilities of a variety and the degree of its realization under different climate conditions and cultivation technologies. Therefore, identification of the varietal composition of this crop with different adaptive features and types of development by the parameters of phenotypic plasticity and yield stability is very topical at present and has great practical importance.

In the Southern Steppe of Ukraine this biological phenomenon contributes to active plant growth in spring during short days that allows efficient use of moisture and intensive formation of biological yield [2-3]. Some winter wheat varieties are characterized by these characteristics in certain years and behave as "spring-winter crops" under appropriate environmental conditions. It allows using them effectively under late sowing dates, when "typically" winter wheat varieties develop slowly and reduce potential productivity. The use of a positive effect of this interaction in production conditions, 
through optimization of the varietal composition of wheat for particular agro-ecological conditions and implementation of "spring-winter crops" into crop production as a complementary crop will certainly contribute to an increase in the competitiveness of wheat varieties of different types of development.

The principal objective of the research was to determine winter wheat productivity under irrigated and non-irrigated conditions.

Task setting. A variety should be considered in terms of its reaction to environmental conditions and capability of realizing genetic material in a particular ecological region. Each variety can have its own set of limiting factors for productivity in stressful situations. We conducted evaluation of winter wheat varieties of the Institute of Breeding and Genetic of UAAS (Odesa), Krasnodar Research Institute of Agriculture (RF) and the Institute of Agriculture of the Southern Region of UAAS (Kherson).

Winter wheat is quite resistant to low temperatures. When hardened enough, winter wheat can endure the temperature up to $-25^{\circ} \mathrm{C}$ in winter. When not hardened enough it can be damaged by frost $\left(14-17^{\circ} \mathrm{C}\right)$.

Winter wheat frost resistance is affected by:

Genetic characteristics of a variety; sowing dates, the phase of "entering" winter; the sugar content the nod of tillering; environmental conditions.

Snow cap protects wheat from a damaging effect of low temperatures. When there is no snow cap, wheat is heavily damaged in most cases at the temperature of $18-19^{\circ} \mathrm{C}$. In addition to low temperatures, ice crust, root injury and rotting can also have a negative impact on winter wheat in winter.

The varieties with a long period of vernalization -40 days and more - are characterized by higher frost resistance. Wheat crops sown at optimal time, having 3 sprouts, with the sugar content in the node of tillering of more than $25 \%$, survive winter better. Optimal sowing dates, sufficient moisture, heat and nutrient supply, and also hardening contribute to the survival of plants.

Main research material. Winter wheat varieties had a high level of plant survival in the winter season.

Table 1

Evaluation of the winter wheat varieties surviving winter

\begin{tabular}{|c|l|c|c|c|}
\hline $\begin{array}{c}\text { № } \\
\mathbf{I} / \mathbf{I}\end{array}$ & \multicolumn{1}{|l|}{ Variety } & $\begin{array}{c}\text { The condition of crops, } \\
\text { (on the } \mathbf{8}^{\text {th }} \text { of November), } \\
\text { point }\end{array}$ & $\begin{array}{c}\text { The condition } \\
\text { of crops (on the } \\
\mathbf{1 5}^{\text {th }} \text { of March), point }\end{array}$ & $\begin{array}{c}\text { Evaluation } \\
\text { of plant } \\
\text { survival, \% }\end{array}$ \\
\hline 1 & Odeska 267 & 9 & 8 & 78 \\
\hline 2 & Tania elita & 9 & 8 & 87 \\
\hline 3 & Hratsiia elita & 9 & 8 & 87 \\
\hline 4 & Bahrat (elita) & 9 & 8 & 86 \\
\hline 5 & Hrom elita & 9 & 8 & 89 \\
\hline
\end{tabular}

The data given in the table show that all the varieties are characterized by high winter hardiness, apart from Odeska 267, its winter hardiness being 78\%. On the whole, early heading was registered in the variety Hrom, this stage started 2-5 days later in the variety Bahrat.

On the average, during the year of the research, the growing season lasted from 281 to 288 days. It was shorter in the varieties Odeska 267 and Bahrat. The growing season lasted 5-8 days longer in the varieties Tania, Hratsiia and Hrom 1. 
Evaluation of the variety resistance to shattering, drooping and fragility of seed-heads, point

\begin{tabular}{|c|l|c|c|c|}
\hline $\begin{array}{c}\text { № } \\
\text { II/II }\end{array}$ & \multicolumn{1}{|c|}{ Variety } & $\begin{array}{c}\text { Resistance } \\
\text { to shattering }\end{array}$ & $\begin{array}{c}\text { Resistance } \\
\text { to seed-head } \\
\text { drooping }\end{array}$ & $\begin{array}{c}\text { Resistance } \\
\text { to seed-head } \\
\text { fragility }\end{array}$ \\
\hline 1 & Odeska 267 & 9 & 9 & 9 \\
\hline 2 & Tania elita & 9 & 9 & 9 \\
\hline 3 & Hratsiia elita & 9 & 9 & 9 \\
\hline 4 & Bahrat (elita) & 9 & 9 & 9 \\
\hline 5 & Hrom elita & 9 & 9 & 9 \\
\hline
\end{tabular}

As the data given in Table 1 show, all the varieties under study had high resistance to lodging, seed-head shattering, drooping and fragility. All these indexes had an impact on the grain yield of the winter wheat varieties under study and its structure.

Table 3

Winter wheat varieties damaged by fungal diseases

\begin{tabular}{|l|c|c|}
\hline \multirow{2}{*}{\multicolumn{1}{|c|}{ Varietal }} & \multicolumn{2}{c|}{ The plants damaged by fungal diseases, \% } \\
\cline { 2 - 3 } & Brown mildew & Powdery mildew \\
\hline Odeska 267 & $15.0 \pm 2.4$ & $20.4 \pm 2.6$ \\
\hline Tania elita & $12.6 \pm 2.6$ & $15.4 \pm 3.0$ \\
\hline Hratsiia elita & $25.8 \pm 2,8$ & $38.0 \pm 3.2$ \\
\hline Bahrat (elita) & $8.1 \pm 0,9$ & $14.8 \pm 2.0$ \\
\hline Hrom elita & $20.4 \pm 2.9$ & $20.5 \pm 2.8$ \\
\hline
\end{tabular}

Some varieties (Bahrat and Tania) had very reliable genetic protection from harmful pathogens.

The growing conditions of winter wheat allowed prolonging the period between the stages of heading - complete maturity, that had a further impact on the level of winter wheat productivity. The growing season and the duration of the periods between stages of winter wheat are given in Table 4.

The data given in Table 4 show that under non-irrigated conditions the variety Bahrat (elita) had the shortest period "seedlings-complete maturity" (265 days). It is 5 days less than in the standard Odeska 267. All the other varieties had insignificant differences in comparison with the standard.

Under irrigated conditions the varieties Tania elita, Hratsiia elita and Bahrat elita had the shortest period "sowing-complete maturity" ( 275 days). It is 8 days less than in the standard.

As Table 4 shows, irrigation contributed to a considerable increase in the growing season of winter wheat from 10 to 18 days.

Crop productivity is an integral index that forms with participation of certain quantitative properties. Therefore, forecasting possibilities of increasing productivity mostly depends on the awareness of main regularities of yield formation, the essence of relationship between individual components and their impact on total productivity.

Productivity should be considered in terms of individual components participating in its formation, since each of them often manifests itself independently and is a result of genetic interaction of many factors and agro-ecological conditions. 
Table 4

The growing season and the duration of the periods between stages in winter wheat varieties

\begin{tabular}{|c|c|c|c|c|c|}
\hline \multirow{2}{*}{$\begin{array}{c}\text { Growing } \\
\text { conditions }\end{array}$} & Variety & $\begin{array}{c}\text { Seedlings- } \\
\text { booting }\end{array}$ & $\begin{array}{c}\text { Booting- } \\
\text { heading }\end{array}$ & $\begin{array}{c}\text { Heading- } \\
\text { complete } \\
\text { maturity }\end{array}$ & $\begin{array}{c}\text { Seedlings- } \\
\text { complete } \\
\text { maturity }\end{array}$ \\
\hline \multirow{4}{*}{$\begin{array}{c}\text { Without } \\
\text { irrigation }\end{array}$} & Odeska 267 & 218 & 17 & 35 & 270 \\
\cline { 2 - 6 } & Tania elita & 220 & 17 & 34 & 271 \\
\cline { 2 - 6 } & Hratsiia elita & 216 & 17 & 34 & 267 \\
\cline { 2 - 6 } & Bahrat (elita) & 214 & 16 & 35 & 265 \\
\cline { 2 - 6 } & Hrom elita & 220 & 16 & 34 & 270 \\
\hline \multirow{4}{*}{ Irrigation } & Odeska 267 & 218 & 15 & 50 & 283 \\
\cline { 2 - 6 } & Tania elita & 216 & 14 & 45 & 275 \\
\cline { 2 - 6 } & Hratsiia elita & 214 & 14 & 47 & 275 \\
\cline { 2 - 6 } & Bahrat (elita) & 214 & 13 & 48 & 275 \\
\cline { 2 - 6 } & Hrom elita & 220 & 16 & 52 & 288 \\
\hline
\end{tabular}

The elements of productivity can be partially compensated by other components that form in more favorable conditions at further stages of ontogenesis.

In order to ensure a high level of winter wheat grain yield it is necessary to manage the formation of each element of productivity and direct the technology of creating an appropriate clearly determined crop structure towards a planned yield.

The yield structure of winter wheat is given in Table 5 .

The number of productive stems forms starting from the $1^{\text {st }}-8^{\text {th }}$ stages of organogenesis and depends on the number of plants per unit area and their tillering The initial (autumn) growth stage of winter wheat is crucial for the formation of productive crop stems. At this time, seedlings emerge, crop density and morphobiotypes of plants are determined.

Analysis of the data in Table 5 shows that growing conditions had a considerable impact on the yield structure of winter wheat.

Table 5

The yield structure of winter wheat varieties depending on growing conditions

\begin{tabular}{|c|l|c|c|c|c|}
\hline \multirow{4}{*}{$\begin{array}{c}\text { Growing } \\
\text { conditions }\end{array}$} & \multicolumn{1}{|c|}{ Variety } & $\begin{array}{c}\text { Ear } \\
\text { length, } \\
\text { cm }\end{array}$ & $\begin{array}{c}\text { Number } \\
\text { of ears, } \\
\text { pcs }\end{array}$ & $\begin{array}{c}\text { Number } \\
\text { of grains } \\
\text { per ear, pcs }\end{array}$ & $\begin{array}{c}\text { Grain } \\
\text { weight per } \\
\text { year, } \\
\text { gea }\end{array}$ \\
\hline \multirow{4}{*}{$\begin{array}{c}\text { Without } \\
\text { irrigation }\end{array}$} & Odeska 267 & 8.0 & 20 & 31.0 & 1.15 \\
\cline { 2 - 6 } & Tania elita & 7.8 & 18 & 33.0 & 1.21 \\
\cline { 2 - 6 } & Hratsiia elita & 7.4 & 17 & 33.5 & 1.20 \\
\cline { 2 - 6 } & Bahrat (elita) & 7.2 & 15 & 30.5 & 1.22 \\
\cline { 2 - 6 } & Hrom elita & 7.6 & 16 & 30.9 & 1.17 \\
\hline \multirow{4}{*}{ Irrigation } & Odeska 267 & 10,8 & 21 & 37.5 & 1.30 \\
\cline { 2 - 6 } & Tania elita & 10.4 & 16 & 39.0 & 1.37 \\
\cline { 2 - 6 } & Hratsiia elita & 10.2 & 18 & 38,7 & 1.40 \\
\cline { 2 - 6 } & Bahrat (elita) & 10.8 & 16 & 39.4 & 1.42 \\
\cline { 2 - 6 } & Hrom elita & 10.6 & 15 & 33.7 & 1.28 \\
\hline
\end{tabular}


The elements of productivity of a main ear has certain dependence on growing conditions. For instance, under irrigated conditions the length of an ear increases from 2.8 $\mathrm{cm}$ (in the variety Odeska 267) to $3.6 \mathrm{~cm}$ (in the variety Bahrat elita) on the average in comparison with non-irrigated conditions.

We have not established a considerable impact of growing conditions on the number of spikes of a main ear.

The largest grain weight per ear under irrigated conditions was characteristic of the varieties Hratsiia elita $(1.40 \mathrm{~g})$ and Bahrat elita $(1.42 \mathrm{~g})$. It is larger than that of the standard by $0.10 \mathrm{~g}$ and $0.12 \mathrm{~g}$ respectively.

The impact of growing conditions on the level of productivity of winter wheat varieties is given in Table 6 .

Table 6

\section{Productivity of winter wheat varieties under different growing conditions}

\begin{tabular}{|c|c|c|c|c|}
\hline \multirow{2}{*}{$\begin{array}{l}\text { Growing } \\
\text { conditions }\end{array}$} & \multirow{2}{*}{ Variety } & \multirow{2}{*}{ Yield, c/ha } & \multicolumn{2}{|c|}{ Deviation } \\
\hline & & & c/ha & $\%$ \\
\hline \multirow{5}{*}{$\begin{array}{l}\text { Without } \\
\text { irrigation }\end{array}$} & Odeska 267 & 28.3 & - & - \\
\hline & Tania elita & 26.9 & -1.4 & -4.9 \\
\hline & Hratsiia elita & 30.3 & +2.0 & +7.1 \\
\hline & Bahrat (elita) & 31.6 & +3.3 & +11.7 \\
\hline & Hrom elita & 27.5 & -0.8 & -2.8 \\
\hline \multirow{5}{*}{ Irrigation } & Odeska 267 & 57.9 & - & - \\
\hline & Tania elita & 56.1 & $-1,8$ & -3.1 \\
\hline & Hratsiia elita & 59.4 & +1.5 & +2.6 \\
\hline & Bahrat (elita) & 60.7 & +2.8 & +4.8 \\
\hline & Hrom elita & $56, .4$ & -1.5 & $-2,6$ \\
\hline & LSD05 & \multicolumn{3}{|c|}{$\begin{array}{l}\text { For factor } \mathrm{A}-2.71 \\
\text { For factor } \mathrm{B}-0.30 \\
\text { Interaction of Factors } \mathrm{AB}-2.93 \text {. }\end{array}$} \\
\hline
\end{tabular}

Analysis of the obtained results shows that the varieties Bahrat and Hratsiia had the highest yields under irrigated and non-irrigated conditions. The yields of these varieties exceeded that of the standard Odeska 267. In particular, the variety Bahrat had the yield of $31.6 \mathrm{c} /$ ha under non-irrigated conditions and $60.7 \mathrm{c} / \mathrm{ha}$ under irrigated conditions.

Conclusions and propositions. Comparative evaluation of winter wheat varieties of late generations by the level of their environmental resistance and criteria of the adaptive system of optimizing varietal composition made it possible to determine different levels of intensity, genetically and biologically heterogeneous varieties that allows using agro-ecological potential of each zone efficiently. The study presents theoretical generalization and a new solution to the problem of increasing winter wheat productivity on the basis of selecting better complementary varieties under conditions of a particular region.

\section{REFERENCES:}

1. Базалій В. Принципи адаптивної селекції озимої пшениці в зоні південного Степу. Херсон : Айлант, 2004. 244 с.

2. Бондаренко В., Артюр О., Хмара В. Морозостійкість, зимостійкість і врожай озимої пшениці в залежності від умов зволоження і живлення рослин. Вісник сільськогосподарської науки. 1975. № 10. С. 22-26. 
3. Литвиненко М. Теоретичні основи та методи селекції озимої м'якої пшениці на підвищення адаптивного потенціалу для умов Степу України : автореф. дис. ... д-ра с.-г. наук : 06.01.05. Київ, 2001. 46 с.

4. Орлюк А., Усик Л. Мінливість сортів озимої м'якої пшениці за морфометричними ознаками. Таврійський науковий вісник. 2004. № 34. С. 194-201.

УДК 635.63:632.26:632.4.01/08:632.938.1

DOI https://doi.org/10.32851/2226-0099.2021.118.4

\title{
ПОШИРЕНІСТЬ I ШКІДЛИВІСТЬ ОСНОВНИХ ЗАХВОРЮВАНЬ ОГІРКІВ ТА ІМУНІТЕТ КУЛЬТУРИ
}

\author{
Бондаренко С.В. - к.С.-е.н., \\ старший викладач кафедри агрохімії, \\ Харківський національний аграрний університет імені В.В. Докучаєва \\ Станкевич С.В. - к.С.-2.н., Әоцент, \\ доцент кафедри зоології та ентомології імені Б.М. Литвинова, \\ Харківський національний аграрний університет імені В.В. Докучаєва
}

В Україні огірок (Cиситіs sativus Linneus) щзорічно займає близько 20\% від загальної площі всіх посівних овочевих культур у відкритому грунті, або 52,6 тис. га. Основною причиною, щуо істотно знижуе кількісні та якісні показники основних изіних господарських ознак иієї овочевої культури, є висока захворюваність товарних посівів хворобами, особливо несправжньою борошнистою росою (Pseudoperonospora cubensis (Berk. \& M.A. Curtis) Rostovtsev).

З 1985 року в Україні ияя хвороба огірка у відкритому грунті на нестійких сортах постійно мала сильний розвиток, в окремі роки розвиток відбувався за типом епіфітотії. Водночас недобір товарного врожаю ијєї овочевої культури через ураження пероноспорозом у польових умовах може досягати 50-80\% і більше, а втрата насіння - 25-70\%.

Однією з основних причин значних втрат товарного врожаю і насіння огірка корнішонного типу в умовах його вирощування у відкритому трунті визнана висока сприйнятливість сортозразків до низки захворювань, зокрема несправжньої борочнистої роси (Pseudoperonospora cubensis (Berk. \& M.A. Curtis) Rostovtsev). На жаль, ияя проблема залишалася актуальною для України протягом останніх кількох десятиліть.

Отже, отримання вихідного матеріалу огірка корнішонного типу з гармонійним поєднанням у генотипах комплексу різних цінних господарських характеристик (врожайність, якість, стійкість до хвороб, вміст хімічних речовин, придатність до різних видів обробки) і створення сучасного конкурентоспроможного інноваційного продукту (сорт, гібрид) на його основі залишається актуальним і пріоритетним завданням вітчизняної аграрної науки.

Водночас ученими доведено, щуо впровадження у виробництво складних (інтегрованих) систем, які передбачають біологізацію захисту з перекладом ї̈ на еколого-економічну основу, сьогодні визнано найбільш перспективним. Окремо наголошується, шо саме використання стійких сортів (гібридів) у таких інтегрованих системах дає найбільший економічний ефект.

Авторами виконаний ретельний критичний аналіз вітчизняної $і$ світової літератури про теоретичне і практичне значення ознаки довготривалої стійкості огірка корнішонного типу до основних захворювань при різних умовах і технологіях вирошування, особливості фітопатологічного комплексу огірка корнішонного типу і генного комплексу (імунітету) стійкості до основних захворювань.

Ключові слова: огірок, хвороби, поширеність, шкідливсть, фітопатологічний комплекс, імунітет, ознаки довготривалої стабільності. 